\title{
KEABSAHAN PEMBATALAN HIBAH AKIBAT PEMBERI HIBAH JATUH MISKIN
}

\author{
Oktaviana Adhani \\ Magister Kenotariatan, Fakultas Hukum, Universitas Surabaya \\ Email: mynizly@yahoo.com \\ Bagiyo Atmaja \\ Magister Kenotariatan, Fakultas Hukum, Universitas Surabaya
}

\begin{abstract}
A grant is a gift that starts in effect since it is implemented. not infrequently the grant as a voluntary gift raises problems that occur because there are other parties who raise objections to the grant. This study analyzes the validity of grants to minors represented by their mothers and the legal position of cancellation of grants due to poor grants. The research method used is normative juridical by using the statutory approach and conceptual approach. The results of the study showed that the grants for the inheritance of the giver of grants to minors and received by their mothers were legal. The provisions in the Civil Code govern that grants can be revoked and canceled The word "can be canceled", which means that the grant made is not null and void by law, but must be canceled by submitting a request for cancellation at the Court.

Keywords: Grant, Agreement, Cancellation
\end{abstract}

Abstrak
Hibah merupakan suatu pemberian yang mulai berlaku sejak dilaksanakan. tidak jarang hibah sebagai suatu pemberian secara sukarela tersebut menimbulkan permasalahan yang terjadi karena terdapat pihak lain yang mengajukan keberatan atas hibah tersebut. Penelitian ini menganalisis keabsahan hibah kepada anak dibawah umur yang diwakili ibunya dan kedudukan hukum pembatalan hibah akibat pemberi hibah jatuh miskin. Metode penelitian yang digunakan adalah yuridis normatif dengan menggunakan pendekatan perundang-undangan dan pendekatan konseptual. Hasil penelitian menunjukkan bahwa hibah atas harta bawaan pemberi hibah kepada anak yang belum dewasa dan diterima oleh ibunya adalah sah. Ketentuan dalam KUHPerdata mengatur bahwa hibah dapat dicabut dan dibatalkan Kata "dapat dibatalkan", yang berarti bahwa hibah yang dibuat tidak batal demi hukum, melainkan harus dibatalkan dengan mengajukan permohonan pembatalan pada Pengadilan.

Kata Kunci: Hibah, Perjanjian, Pembatalan

\section{Pendahuluan}

Hibah merupakan suatu pemberian yang mulai berlaku sejak saat itu atau sebagai suatu pemberian tentunya antara penghibah dengan penerima hibah saling mengenal dan sebagai wujud saling mengenal inilah akhirnya pemberi memberikan hibah kepada orang lain. Sebagai pemberian kadangkala si penerima langsung menerima hak milik atas barang 
yang diperoleh berdasarkan hibah dan melakukan suatu perbuatan hukum atas obyek hibah. Namun tidak jarang hibah sebagai suatu pemberian secara sukarela tersebut menimbulkan permasalahan yang terjadi karena terdapat pihak lain yang mengajukan keberatan atas hibah tersebut.

Hibah kepada seseorang yang karena hubungan darah, terlarang untuk kawin; hibah antara suami isteri dan sebaliknya; bilamana pemberi hibah atau penerima hibah telah meninggal dunia, baik salah satu pihak maupun kedua-duanya; bila barang yang dihibahkan itu telah hilang atau hancur; bila barang yang dihibahkan itu telah dipindahtangankan oleh si pemberi hibah, baik dijual, diberikan kembali, atau dengan cara-cara lain; bila barang yang dihibahkan itu telah bertambah nilainya karena sesuatu sebab apa pun; bila pemberi hibah telah mendapatkan suatu penggantian untuk hibah tersebut. Hibah-hibah semasa hidup sekali-kali tidak boleh dikurangi, kecuali bila ternyata bahwa semua harta benda yang telah diwasiatkan tidak cukup untuk menjamin legitieme portie. Bila hibahhibah semasa hidup pewaris harus dikurangi, maka pengurangan harus dimulai dan hibah yang diberikan paling akhir, ke hibah-hibah yang dulu-dulu. (Suparman, 2005)

Hibah orang tua dalam hal ini ayah kepada anaknya yang masih di bawah umur yang bertindak sebagai penerima hibah yang mewakili anaknya ternyata dapat menjadi masalah, karena setelah hibah terlaksana, pihak istri yang mewakili anak penerima hibah meminta cerai dan oleh pengadilan diberikan hak asuh terhadap anak, dan menguasasi harta hibah anak yang masih di bawah umur sebagaimana kasus suami istri mengikatkan diri dalam suatu perkawinan, dari hasil perkawinannya lahir dua orang anak yang masih dibawah umur. Ketika perkawinannya masih berlangsung, istrinya menghendaki seluruh harta baik harta asal maupun harta bersama dihibahkan kepada kedua anaknya. Penghibah adalah ayah dari anak tersebut sedangkan penerima hibah ibu dari anak yang mewakili anaknya yang belum dewasa. Setelah hibah dibuat dalam suatu bentuk akta hibah, istri mengajukan gugat cerai, sehingga menguasai seluruh harta benda dalam keluarga untuk dan atas nama kedua anaknya tersebut. Pihak suami merasa keberatan, karena seluruh harta tersebut dikuasai oleh istrinya, dan dihibahkan seluruh harta tersebut, menjadikan kehidupan suami/ayah penerima hibah sejak terjadinya perceraian kondisinya menjadi miskin

\section{Rumusan Masalah}

1) Apakah Hibah kepada anak dibawah umur yang diwakili ibunya adalah sah?

2) Apa kedudukan hukum pembatalan hibah akibat pemberi hibah jatuh miskin?

\section{Metode Penelitian}

Metode yang digunakan dalam penelitian ini adalah metode penelitian yuridis normatif yang menekankan pada norma-norma hukum dengan menganalisa peraturan perundang-undangan terkait. Dalam Penelitian ini peneliti menggunakan dua metode 
pendekatan masalah yaitu : 1) Statute Approach, pendekatan dengan menelaah semua peraturan perundang-undangan yang bersangkut paut dengan permasalahan (isu hukum) yang sedang dihadapi. 2) Conseptual Approach, yaitu pendekatan yang beranjak dari pandangan-pandangan dan doktrin-doktrin yang berkembang di dalam ilmu hukum. (Peter Mahmud Marzuki, 2010).

\section{Keabsahan Hibah Kepada Anak Dibawah Umur Yang Diwakili Ibunya}

Hibah atau Pemberian dalam hal ini sebenarnya termasuk dalam pengertian Hukum, karena mempunyai ketentuan-ketentuan hukum sendiri. Pada umumnya proses tersebut terjadi secara terpisah, yaitu tidak terjadi pada saat yang bersamaan melainkan ada tenggang waktu tertentu sesuai dengan suasana saat itu, jadi sifat dari pemberian itu adalah umum, karena baik pemberi maupun penerima tidak perlu memenuhi kewajiban tertentu kecuali ada kerelaan para pihak dan tidak melihat status individunya.

Untuk hibah dengan obyek tanah merupakan pemberian seseorang kepada orang lain dengan tidak ada penggantian apapun dan dilakukan secara suka rela, tanpa ada kontraprestasi dari pihak penerima pemberian, dan pemberian itu dilangsungkan pada saat si pemberi hibah masih hidup. (Utomo, 2019) Ini berbeda dengan wasiat, yang mana wasiat diberikan sesudah si pewasiat meninggal dunia. Menurut Pasal 1666 KUH Perdata: Hibah adalah suatu perjanjian dengan mana si penghibah, diwaktu hidupnya, dengan cuma-cuma dan dengan tidak dapat ditarik kembali, menyerahkan sesuatu barang guna keperluan si penerima hibah yang menerima penyerahan itu. (Prawirohamidjojo \& Pohan, 2008)

Berdasarkan rumusan di atas, dapat diketahui unsur-unsur hibah sebagai berikut :

1. Pada bagian pertama memuat ketentuan-ketentuan umum yang terdiri dari pengertian hibah, hibah oleh orang hidup, barang yang dihibahkan, syahnya hibah dan syarat-syarat hibah.

2. Pada bagian kedua memuat tentang kemampuan untuk memberikan dan menerima hibah yang berisi tentang orang-orang yang berhak memberikan dan menerima hibah dan hibah antara suami istri.

3. Bagian ketiga memuat cara menghibahkan sesuatu yang berisi tentang pembuatan akta hibah pada, hibah kepada wanita dan kepada anak-anak di bawah umur.

4. Bagian keempat memuat tentang pencabutan dan pembatalan hibah yang berisi tentang syarat-syarat pencabutan dan pembatalan hibah.

Penghibahan hanyalah dapat mengenai barang-barang yang sudah ada. Jika ia meliputi barang-barang yang baru di kemudian hari, maka sekedar mengenai itu hibahnya adalah batal (Pasal 1667 KUH Perdata). Berdasarkan ketentuan ini maka jika dihibahkan suatu barang yang sudah ada, bersama-sama dengan suatu barang lain yang baru di kemudian hari, penghibahan yang mengenai barang yang pertama 
adalah sah, tetapi mengenai barang yang kedua adalah tidak sah. Namun demikian, padi yang belum menguning disawah seluas satu hektar dapat dihibahkan. Karena padi itu merupakan barang yang ada dan merupakan sebagian harta benda milik pemberi hibah. Setiap bagian dari harta benda milik pemberi hibah dapat dihibahkan. Sebaliknya, berbuat sesuatu dengan cuma-cuma, seperti: mengetik naskah dengan disediakan kertas dan mesin tik oleh penulis naskah tanpa diberi hadiah atau imbalan, berbuat dan tidak berbuat itu tidak merupakan bagian dari harta benda (Muhammad, 2000).

Berdasarkan uraian tersebut di atas bahwa berikut ini syarat- syarat pemberi dan penerima hibah dan tata cara hibah berdasarkan KUH Perdata :

a. Pemberi hibah harus sudah dewasa, yakni cakap menurut hukum, kecuali dalam hak yang ditetapkan dalam bab ke tujuh dari buku ke satu KUH Perdata (Pasal 1677 KUH Perdata)

b. Suatu hibah harus dilakukan dengan suatu akta notaris yang aslinya disimpan oleh notaris (Pasal 1682 KUH Perdata)

c. Suatu hibah mengikat si penghibah atau menerbitkan suatu akibat mulai dari penghibahan dengan kata-kata yang tegas yang diterima oleh si penerima hibah (Pasal 1683 KUH Perdata)

d. Penghibahan kepada orang yang belum dewasa yang berada di bawah kekuasaan orang tua harus diterima oleh orang yang melakukan kekuasaan orang tua (Pasal 1685 KUH Perdata).
Subyek Hibah Dalam Hukum Perdata bisa siapa saja, namun ada beberapa pengecualian tertentu, misalnya saja anak-anak di bawah umur. (Utomo, 2017) Anak di bawah umur diangap tidak kuasa menerima maupun memberi hibah. Meraka dilarang membuat persetujuan hibah atau sesuatu barang apapun. Hibah yang mereka perbuat dapat diminta pembatalanya (vernietingbaar) namun bukan batal dengan sendirinya. (Manan, 2008)

Hibah kepada anak-anak di bawah umur yang masih di bawah kekuasaan orang tua, harus diterima oleh orang yang menjalankan kekuasaan orang tua itu, sedangkan hibah kepada anak-anak di bawah umur yang masih di bawah perwalian atau kepada orang yang ada di bawah pengampuan, harus diterima oleh wali atau pengampunya yang telah diberi kuasa oleh pengadilan negeri. Jika pengadilan itu memberi kuasa termaksud, maka hibah itu tetap sah, meskipun penghibah telah meninggal dunia sebelum terjadi pemberian kuasa itu. Hibah kepada anak di bawah umur yang masih di bawah perwalian atau kepada orang yang ada di bawah pengampuan, harus diterima oleh wali atau pengampunya yang telah diberi kuasa oleh pengadilan negeri. (Prawirohamidjojo \& Pohan, 2008)

KUH Perdata tidak menyebutkan secara tegas mengenai syarat-syarat hibah. Akan tetapi, dengan melihat Pasal 1666 KUH Perdata maka dapat ditarik suatu kesimpulan bahwa syarat-syarat hibah dalam KUH Perdata, diantaranya adalah Adanya Perjanjian, Penghibah, Penerima 
Hibah, dan Barang Hibah. Pemberian Hibah tidak boleh mengakibatkan ahli waris menjadi tidak berhak atas harta peninggalan/warisan si penghibah. Pemberian hibah tidak boleh mengurangi atau meniadakan pembagian waris bahkan legitimatie portie masing-masing ahli waris. Apabila pembagian ataupun pemberian hibah dirasakan merugikan kepentingan ahli waris yang sah, maka ahli waris tersebut dapat menuntut untuk dibatalkannya hibah tersebut. Namun dalam hal hibah jika penerima hibah melakukan perbuatan tidak patut kepada pemberi hibah maka pemberi hibah dapat menarik kembali hibah tersebut.

Para praktisi hukum harus benar-benar mengerti dan memberikan edukasi agar pemberian hibah yang mereka lakukan tidak melanggar ketentuan hukum dan merugikan ahli waris dan perlu adanya ketentuan hukum yang mengatur hibah untuk setiap golongan ras dan agama agar diperoleh suatu kepastian tentang pelaksanaan hibah. Ketentuan yang sudah ada juga juga harus di buat secara tertulis dan di undangkan agar setiap orang dan prakrisi hukum memiliki kepahaman tentang hibah, dan penegasan yang di tuangkan dalam suatu klausul sehingga akan terang dan jelas. Dalam pelaksanaan pemberian hibah, si pemberi hibah harus sudah dewasa, sehat pikiran serta bukan suami isteri. (Utomo, 2018)

Selain itu mulai hari penghibahan itu dengan kata-kata yang tegas telah diterima oleh si penerima hibah sendiri atau dikuasakan untuk menerima penghibahan-penghibahan yang telah diberikan kepada si penerima hibah atau akan diberikan kepadanya di kemudian hari. Apabila pelaksanaan pemberian hibah tersebut tidak dilakukan di dalam surat hibah sendiri, maka hal itu akan dapat dilakukan di dalam suatu akta otentik kemudian, yang aslinya harus disimpan, asalkan hal ini dilakukan diwaktu si pemberi hibah masih hidup. (H, 2008)

Hibah orang tua kepada anak di bawah umur yang masih berada di bawah kekuasaan orangtua, harus diterima oleh orang yang menjalankan kekuasaan orangtua itu. Hibah kepada anak-anak di bawah umur yang masih di bawah perwalian atau kepada orang yang ada di bawah pengampuan, harus diterima oleh wali atau pengampunya yang telah diberi kuasa oleh Pengadilan Negeri. Jika pengadilan itu memberi kuasa termaksud maka hibah itu tetap sah meskipun penghibah telah meninggal dunia sebelum terjadi pemberian kuasa itu.

Hibah kepada anak di bawah umur yang masih berada di bawah kekuasaan orang tua menurut Pasal 1685 KUH Perdata, harus diterima oleh orang yang menjalankan kekuasaan orang tua itu. Namun tidak memberikan penjelasan mengenai orang yang menjalankan kekuasaan orang tua itu, apakah ayah dari anak tersebut atau ibu dari anak, yang berarti bahwa jika kedua orang tua menghibahkan harta bendanya kepada anak-anaknya, maka kedua orang tua tersebut tidak dapat bertindak sebagai kuasa dari 
anak untuk menerima hibah tersebut. Hibah kepada anak-anak di bawah umur yang masih di bawah perwalian atau kepada orang yang ada di bawah pengampuan, harus diterima oleh wali atau pengampunya yang telah diberi kuasa oleh Pengadilan Negeri.

\section{Kedudukan Hukum Pembatalan Hibah Akibat Pemberi Hibah Jatuh Miskin}

Itikad baik adalah versi "Nederland yang diambil dari hukum Romawi: bona fides. Arti fides sesungguhnya "kepercayaan" pada kebajikan seseorang, artinya dapat dipercaya, cermat. Orang tua yang diberi kepercayaan untuk mengurus harta kekayaan anak haruslah bijak dan pemanfaatan harta kekayaan anak tersebut dengan cermat. Asas itikad baik (good faith) merupakan salah satu sendi terpenting dalam hukum perjanjian. Perjanjian dengan itikad baik adalah melaksanakan perjajian dengan mengandalkan normanorma kepatutan dan kesusilaan. (Subekti, 2008)

Soetojo Prawirohamidjojo mengemukakan bahwa orang yang mendapat kepercayaan menyatakan secara susila adalah baik, artinya "tulus" dan baik. Salah satu konteks yang menggunakan pengertian bona fides, adalah hukum. Sasaran hukum, adalah perbuatan-perbuatan manusia. Oleh karena itu, kata bona fides dalam arti ilmu hukum juga terlibat dalam peruatan-peruatan manusia; sehingga hukum menuntut agar dalam peruatan ini bona fides dalam arti ilmu hukum juga terlibat dalam perbuatan-perbuatan manusia; sehingga hukum menuntut agar dalam peruatan ini bona fides harus ditepai. Berbuat menurut bona fides pada hakekatnya, adalah berbuat baik, jujur dan tulus". (Prawirohamidjojo \& Pohan, 2008)

Pengertian mengenai itikad baik/good faith dalam kontrak secara jelas dipaparkan dalam Simposium Hukum Perdata Nasional yang diselenggarakan Badan Pembinaan Hukum Nasional (BPHN) yang dikutip dari Agus Yudha Hernoko (2008, hlm. 141) menentukan bahwa itikad baik hendaknya diartikan sebagai berikut:

1. Kejujuran dalam membuat kontrak;

2. Pada tahap pembuatan ditekankan, apabila kontrak dibuat di hadapan pejabat, para pihak dianggap beritikad baik (meskipun ada juga pendapat yang menyatakan keberatannya);

3. Sebagai kepatutan dalam tahap pelaksanaan, yaitu terkait suatu penilaian baik terhadap perilaku para pihak dalam melaksanakan apa yang telah disepakati dalam kontrak, semata-mata bertujuan untuk mencegah perilaku yang tidak patut dalam pelaksanaan kontrak tersebut.

Seorang wanita mempunyai dua orang anak dari hasil perkawinan sebelumnya sebelum kawin dengan seorang laki-laki menghendaki harta bendanya sebagai harta bawaan untuk menghibahkan kepada kedua anak dari wanita tersebut sebagai persyaratan perkawinan. Hibah tersebut telah dilaksanakan dan sebagai penerima hibah adalah ibu dari kedua anak tersebut, setelah perkawinan dilangsungkan dan hibah dibuat, wanita tersebut 
sebagai istri mengajukan gugat cerai. Hibah sebagaimana tersebut di atas dibuat dibuat oleh suami kepada kedua anak dan diterima oleh istrinya sebagai kuasa arau wali dari anak yang belum dewasa dari hasil perkawinan dengan suami sebelumnya. Hibah sebagai syarat kesediaan untuk dikawin, namun setelah perkawinan berlangsung dan hibah telah dibuat, pihak istri mengajukan gugat cerai, yang berarti bahwa hibah tersebut dibuat karena adanya keinginan istri menguasai obyek hibah, maka tindakan istri sebagai wali penerima hibah atas asas itikad tidak baik atau tidak jujur atau tidak tulus yang dilakukan oleh istrinya.

Memperhatikan uraian sebagaimana tersebut di atas dapat dijelaskan bahwa itikad baik dikatkian dengan kejujuran dan ketulusan dan dalam membuat perjanjian mengandalkan normanorma kepatutan dan kesusilaan. Oleh karena itikad baik mengarah pada perjanjian dibuat secara jujur dan tidak melanggar kesusilaan, maka jika perjanjian dibuat tidak dengan itikad baik atau tidak jujur, maka perjanjian tersebut dibuat tidak memenuhi syarat sahnya perjanjian syarat suatu sebab yang halal sebagaimana Pasal 1320 ayat (4) KUH Perdata. Sebagai ilustrasi tersebut menunjukkan bahwa para pihak tidak jujur dalam tujuan pembuatan kontrak/perjanjian karena perjanjian yang dibuat tidak sesuai dengan tujuan yang sebenarnya. Perjanjian tersebut secara hukum telah batal dan dengan batalnya perjanjian tersebut maka tentunya merugikan para pihak dalam perjanjian tersebut.
Hibah sebagaimana diatur dalam Pasal 1688 KUH Perdata, yang menentukan bahwa:

Suatu penghibahan tidak dapat dicabut dan karena itu tidak dapat pula dibatalkan, kecuali dalam hal-hal berikut:

1. jika syarat-syarat penghibahan itu tidak dipenuhi oleh penerima hibah;

2. jika orang yang diberi hibah bersalah dengan melakukan atau ikut melakukan suatu usaha pembunuhan atau suatu kejahatan lain atas diri penghibah;

3. jika penghibah jatuh miskin sedang yang diberi hibah menolak untuk memberi nafkah kepadanya.

Di antara diperkenankan mencabut hibah jika penghibah jatuh miskin sedang yang diberi hibah menolak untuk memberi nafkah kepadanya. Apabila dikaitkan dengan ketentuan Pasal 1338 ayat (2) KUH Perdata, yang menentukan: "Perjanjian itu tidak dapat ditarik kembali selain dengan kesepakatan kedua belah pihak, atau karena alasan-alasan yang ditentukan oleh undang-undang". Hibah sebagai suatu perjanjian tidak dapat dicabut selain sepakat kedua belah pihak, atau karena alasan-alasan yang ditentukan oleh undang-undang. Pencabutan hibah tersebut tidak perlu meminta persetujuan kepada penerima hibah, melainkan pencabutan diperkenankan karena menurut Pasal 1688 angka 3 KUH Perdata, pencabutan tersebut diperkenankan oleh penghibah yang karena sesuatu sebab jatuh miskin. 
Kejujuran dalam membuat suatu perjanjian (hibah) mempengaruhi sahnya perjanjian dalam arti bahwa jika hibah dibuat atas dasar istri sebagai penerima hibah untuk anaknya yang belum dewasa itikadnya tidak baik, maka perjanjian atau hibah tersebut dibuat tidak memenuhi syarat sahnya perjanjian yaitu syarat obyektif yaitu suatu sebab yang halal. Hibah sebagai suatu perjanjian jika dibuat tidak memenuhi syarat sahnya perjanjian yaitu syarat suatu sebab yang halal, maka perjanjian tersebut batal demi hukum.

Ketentuan Pasal 1688 KUH Perdata menentukan bahwa jika syarat hibah tidak terpenuhi maka pemberi hibah dapat mencabut dan atau dapat meminta agar hibah tersebut dibatalkan. Kata "dapat", bukan berarti bahwa hibah tersebut batal demi hukum, melainkan batalnya hibah atas dasar putusan pengadilan atas permohonan agar hibah dibatalkan. Namun jika dikaitkan dengan ketentuan Pasal 1686 angka 3 KUH Perdata, bahwa suatu penghibahan tidak dapat dicabut dan karena itu tidak dapat pula dibatalkan, kecuali dalam halhal jika penghibah jatuh miskin sedang yang diberi hibah menolak untuk memberi nafkah kepadanya. Pengadilan "dapat" membatalkan hibah dan dapat pula Pengadilan menolak permohonan pembatalan hibah tersebut.

\section{Kesimpulan}

Hibah atas harta bawaan pemberi hibah kepada anak yang belum dewasa dan diterima oleh ibunya adalah sah. Hibah dilarang antara suami kepada isteri dan sebaliknya selama perkawinan mereka masih berlangsung, sesuai Pasal 1678 KUH Perdata. Hibah harta asal dan harta bersama dalam perkawinan seorang bapak kepada anak yang usianya kurang dari 18 tahun dan belum pernah kawin sebagaimana ditentukan dalam Pasal 47 UU No. 1 Tahun 1974, bahwa setiap perbuatan hukum oleh anak baik di dalam maupun di luar pengadilan berada di bawah kekuasaan orang tuanya atau walinya, hibah suami kepada anak kandungnya yang belum dewasa di bawah kekuasaan ibu kandungnya, maka selama hibah dibuat memenuhi syarat sahnya hibah, maka hibah tersebut sah.

Akibat hukum Istri meminta suami memberi hibah kepada anak yang belum dewasa dan kemudian penghibah jatuh miskin, bahwa merujuk pada Pasal 1686 angka 3 KUH Perdata, bahwa hibah dapat dicabut dan dibatalkan, ketika penghibah jatuh miskin sedang yang diberi hibah menolak untuk memberi nafkah kepadanya. Kata "dapat dibatalkan", yang berarti bahwa hibah yang dibuat tidak batal demi hukum, melainkan harus dibatalkan dengan mengajukan permohonan pembatalan pada Pengadilan. Pengadilan "dapat" membatalkan hibah dan dapat pula Pengadilan menolak permohonan pembatalan hibah tersebut.

\section{Daftar Pustaka}

H, Zainuddin. (2008). Pelaksanaan Hukum Waris Di Indonesia. Jakarta: Sinar Grafika.

Manan, A. (2008). Aneka Masalah Hukum Perdata di Indonesia. 
Jakarta: Kencana Pranada Kartini.

Muhammad, A. (2000). Hukum Perdata Indonesia. Bandung: Citra Aditya Bakti.

Prawirohamidjojo, R. S., \& Pohan, M. (2008). Hukum Orang dan Keluarga (Personen En FamilieReccht). Surabaya: Airlangga University Press.

Subekti, R. (2008). Aneka Perjanjian. Jakarta: Sinar Grafika.

Suparman, E. (2005). Hukum Waris Indonesia. Bandung: Refika Aditama.

Utomo, H. I. (2019). Memahami Pelaksanaan Tugas Jabatan Pejabata Pembuat Akta Tanah. Yogyakarta: Phoenix Publisher.

Utomo, H. I. (2018). Hukum Tanah Nasional : Bahan Diskusi Dalam Persiapan Menghadapi Ujian Pejabat Pembuat Akta Tanah 2017. Belajar Bareng Alumni (hal. 27). Surabaya: Universitas Narotama.

Utomo, H. I. (2017). Pelaksanaan Tugas Jabatan Notaris : Bahan Diskusi Dalam Persiapan Menghadapi Ujian Kode Etik Notaris. Surabaya: Belajar Bareng Alumni Universitas Narotama. 